\title{
The Social Needs of the Elderly in South Bangka
}

\author{
Yeniar Indriana ${ }^{1}$, Chamilul Hikam Al Karim ${ }^{2}$, Arif Febrianto ${ }^{3}$, Dedy Yuni Hardi ${ }^{4}$ \\ ${ }^{1,2}$ Faculty of Psychology, Diponegoro University \\ Prof. Soedarto, SH. Street, Tembalang, Semarang \\ ${ }^{3}$ Service Secretary, Department of Maritime Affairs and Fisheries, Bangka Belitung \\ ${ }^{4}$ Head of Research and Development in South Bangka Regency
}

\begin{abstract}
The social needs of the elderly in the South Bangka Regency were expressed through the needs of affiliation, succorance, and deference. These needs seem to dominate the behavior of the elderly out there. Social ties with neighbours are very strong and each of them avoids conflicts or disputes. This study aimed to see which social needs were the most dominant among these needs so that the local government could be more appropriate in developing the social welfare programs for the elderly in their regions. This research involved 311 elderly people from 8 (eight) sub-districts in South Bangka Regency. The sampling technique used proportional random sampling based on the area of each district. The results showed that the need for succorance was the most dominant with a mean rank of 548.09, the need for affiliation hit second place with a mean rank of 541.72 and the last one was the need for deference with a mean rank of 311.20. This showed that the need for attention was more dominant than the need to build a relationship and conformity with others. There is no difference in social needs between men and women, nor is there a significant relationship with age.
\end{abstract}

Keywords: Need of affiliation, need of succorance, need of deference, elderly

\section{Introduction}

South Bangka is a district located at the southern tip of Bangka Island, even covering small islands in the Bangka Sea. The population is relatively small which allows its residents to have a fairly large place to live. The elderly out there have never been measured or made research respondents. Most of them are not proficient in Indonesian, so researchers need to be accompanied by officers or local residents when interviewing and collecting data. This is interesting for researchers because it is different from the condition of the elderly in Semarang who are very familiar with interviews and data collection processes. Research conducted by Jagielska (2020) explained that the problem of elderly is a big challenge that must be faced in this $21^{\text {st }}$ century. These challenges in elderly have consequences on social, health, educational and economic policy aspects. The elderly period is a time when humans experience various physical, mental and social degradations. The setback that happened to the elderly made them break away from the society (Sanjaya \& Rusdi, 2012). It is common for the elderly to be underestimated by the community because their movement and physical function have been decreased (Indriana, 2012).

Elderly age is a time when various changes happened. The changes that occur during elderly are not only physical changes but also psychological and social changes (Indriana, 2012; Kail \& Cavanaugh, 2010). Physical changes start in the middle of adulthood which then becomes clearer during elderly. Then, this elderly age is divided into three, namely young old (65-74 years), old old (74-84 years) and oldest old (over 85 years). According to Baltes et. al, the elderly in the oldest old period experienced various challenges such as loss of considerable potential in cognitive potential and ability to learn, increased chronic stress, became increasingly fragile until increased loneliness (Santrock, 2013). In industrialized countries, the number of elderly increases rapidly along with the improvement of various existing health facilities, even the human maximum age can reach 120 years (Kail \& Cavanaugh, 2010). The elderly must face various challenges in order to achieve successful aging and achieve integrity according to Erikson. 
According to Kim and Park (2017), there were at least four main domains in successful aging, namely avoiding disease and disability, having good cognitive function, being actively involved in life and having good psychological function. The successful aging does not only prevent physical and emotional disabilities, but more than that, the perception of elderly about the aging process is more important than the effects of disease and physical disability and depends on attitudes, resilience, optimism, and coping styles (Glicken, 2009). Various factors related to successful aging are lifestyle factors, physical activity factors, psychological factors, spiritual factors and social factors (Medawati et al., 2020). Erikson (in Santrock, 2013) explained that when someone entered the elderly age, they will reflect on the life that they have been lived so far. When elderly experienced satisfaction with their life, they will experience integrity, whereas if they experienced dissatisfaction in life, what appears is only despair. One of the ways to get better understanding in the condition of elderly is by conducting research on existing needs. This study were trying to reveal some of the needs of students, some of which are needs of affiliation, need of succorance and need of deference.

Based on the researcher's observations on the life of elderly in South Bangka Regency, there was a significant difference with elderly in other areas, especially those who lived in Java. They lived on small islands separated by the ocean so that their relationship with their neighbors is so close. They felt that only their neighbors can help them, even though they have children or siblings but live on different islands. Their need to be close to others or neighbors, to always be able to get their attention and help, seemed overwhelming. That is why they seem to obey each other so that there is no conflict with each other. They always try to prevent disagreements and fights and even try to say rhymes or verse when they meet.

The researchers accompanied them in several days, tried to live their life and felt a clear difference with the interaction between neighbors in the researchers' environment. The researchers often did not know when a neighbor was sick if it was not reported in the Neighborhood Association Whatsapp Group. On the other hand, when the researchers or family had to stay several days in the hospital, the neighbors did not even know it. From this observation, the researchers assumed that there are three needs which stand out in them, namely the need for affiliation, which is the need for affiliation and building relationships with others. Second is the need of succorance, which is the need for attention and help from others. The last is the need of deference, which is the need for obedience, conformity and respect.

This research was conducted in the framework of cooperation with local governments in South Bangka Regency. Later, the results of this study will be used as a basis for policy recommendations. Several needs that will be measured in this study are needs of affiliation, needs of succorance and needs of deference. Those needs were chosen because it was assumed that those needs were dominant in elderly. What needs are more dominant and how the dynamics of the three needs are will be the focus of this study.

The need of affiliation is the need to connect, join and group with others. This need of affiliation will lead someone to be kind, always take part with a group of friends, work together or do something with others. They have need for being close in social interactions, being loyal friends, doing somethin for friends, and enjoying to having as many friends as possible. They are also good at building harmonious relationships accompanied by tolerance, warmth and closeness. The presence of others becomes a necessity related to happiness, especially for the elderly. This is related to elderly happiness, namely the feeling of loving or being loved which can encourage elderly to act for others (Hakim \& Hartati, 2014).

One of active aging indicators is also related to the interactions with others in the form of staying socially active indicators (Hoyer \& Roodin, 2009). The study which conducted by Medawati et. al (2020) stated that one of the factors associated with successful aging is social factors or relating to others. So, it can be concluded that connecting with others is important for elderly. The interaction between elderly was different from other age groups. Elderly tends to be more selective in social relationships. In the perspective of socioemotional selectivity theory, it is explained that the elderly have fewer social networks and friends than younger age groups because they emphasize emotional satisfaction (Miller, 2012).

Interaction in humans can be explained through several theories such as interdependence theory, exchange relationship and communal relationship (Taylor et al., 2006). Interdependency theory revealed that the human desire to establish interpersonal relationships is due to the desire to get the maximum benefit at the 
minimum cost. Unlike the previous theory, in the social exchange theory, humans build interpersonal relationships because of the hope of getting benefits when they can do something for others. In short, the social exchange theory explained that humans want to get back after benefiting others.

The communal relationship theory explained that humans have interpersonal relationship because they feel responsible for the welfare of others. Communal relationships usually occur in interactions between family members, friends, and girlfriends. The existence of a communal relationship is a response to the needs of others and is a form of concern. The Interactional Model views human relations as a system consisting of interconnected components, namely input, process and output. Humans have certain expectations, goals and purposes when they want to interact which are called input then. When humans convey a hope that is what is called a process, while the output is the result of the interaction.

The theory of socio-emotional selectivity views that the elderly are not friendless but more selective in socializing. Sabin (in Miller, 2012) explained that elderly who have good relationships with friends or have close friends are healthier than those who are less socializing. Holtzman et. al (in Papalia et al., 2007) explained that the importance of social relationships in elderly is associated with cognitive decline in elderly. Elderly who has a wider social network and frequent social contacts will avoid cognitive decline. Thus, the social relations actually contribute to happiness for elderly (Hakim \& Hartati, 2014). Connecting with others also became an indicator of successful aging in the aspect of staying connected socially.

According to Abraham Maslow (in Olson \& Hergenhahn, 2010), the need to be with others is reflected in the need for love. This need is not only a need to be loved, but also a need to love. When this need for love is not fulfilled, humans will feel lonely, feel alone and feel empty. The need for love and belonging is a encouragement for the individual to have an effective relationship or emotional relationship with others, both in the family environment and outside. Especially, the encouragement to have a place in the middle of the group will suppress it in such a way, so that he will do his best to get a feeling of love and belonging. An individual will experience tremendous isolation and loneliness when he is away from family, friends, groups or life partners. For Maslow, feelings of love and belonging are not only driven by the need for sexuality. However, it is more driven by the need for affection. He agreed with the definition of love by Karl Rogers that love is, "a state of being deeply understood and accepted wholeheartedly". The need for love is very important for the growth and development of someone's abilities. If someone's need for love is not fulfilled or obstructed, it can lead to wrong adjustment. The need for love includes love that gives and love that receives.

The need of affiliation is also related to the need of succorance, that are the need for assistance, expecting help from others if you get into trouble looking for support from others, expecting others to be kind to him, expecting sympathy from others, and understanding the personal problems. The need for help or affection from others is to make others sympathize and understand about themselves and the need to receive support from others. It also includes receiving compassion from others, expecting help from others when they are depressed, expecting forgiveness from others when they make a mistake. High scores on need of succorance indicate the dependence on others and low scores are associated with independence in individuals.

Bernice L. Neugarten, Robert J. Havighurst and Sheldon S. Tobin (in Jagielska, 2020) also mentioned several personality types in elderly such as integrated, defensive, passive dependent and disintegrated. The personality type associated with high needs of succorance is passive dependent that is a personality type characterized by depending on others, seeking support and low adaptation to elderly. Need of succorance is related to the social support received by elderly. The study conducted by Winnubust (in Desiningrum, 2014) stated that social support is inseparable from close relationships with others and social support becomes a dominant factor for elderly's psychological well-being. Desiningrum (2014) said that elderly will feel loved, cared for and appreciated when getting social support so that it can support psychological well-being. Soepardjo (in Hakim \& Hartati, 2014) stated that no matter what the situation is, as a parent, they must be cared by their own family. Cahya et al. (2019) stated there is an important meaning of social support existence in which it is positively related to the life quality of the elderly, so that the better social support, the better the elderly quality of life. The importance of social support is reinforced by a research conducted by Sari et al. (2018) which stated that social support is positively correlated with the elderly quality of life. 
In another study, it was stated that social support is negatively correlated with the tendency of post-power syndrome in retirees (Lailan \& Indriana, 2015).

Indriana (2012) revealed that the physical decline that occurs during the elderly age makes elderly unhappy and tends to be depressed about the existing situation. The presence of others is important in order to overcome depression in the elderly. Perceptions of social support and quality of life are positively related to life satisfaction for elderly (Sahin et al., 2019). The social support received by elderly can make elderly avoid loneliness and depression (Chen et al., 2019). The research conducted by Xie et al. (2018) stated several findings that mentioned subjective support was negatively correlated with depressive symptoms in elderly. Utilization of support correlated negatively with partially dependent depressive symptoms in elderly and it was found that the use of support was more strongly correlated than subjective support for dependent elderly.

A study conducted by Jagielska (2020) divided an attitude into eight, namely Model A (Reorganiser), Model B (Focused), Model C (Disengaged), Model D (Holding on), Model E (Constricted), Model F (Succorance seeking ), Model G (Apatethic), Model H (Disorganized). The attitudes that indicate the amount of the need of succorance or Model F, namely succorance seeking which is characterized by the hope and attention of the loved ones in order to be able to carry out and maintain daily activities and elderly satisfaction is regarded by receiving help from those they are loving.

The elderly not only have a need for help and appreciation from others (need of succorance) but also have a need for conformity and respect for others (need of deference). The elderly in the eastern culture is someone who is highly valued (Indriana, 2012). The behavior of elderly is considered wise and his words always contains advice and kindness. In the context of Javanese culture, elderly is considered to be able to bring disaster or in Javanese it is called kualat if they are not treated properly and politely (Indriana, 2012). In the perspective of Javanese culture, elderly is seen as a person who must be respected or termed as diajeni (in Javanese). The obligation to respect elderly should be carried out by families in particular, because the attitude of the people around elderly is one of the determinant factors of ther succes elderly in living the rest of their life (Suardiman, 2011). In order to have successful aging, elderly need to stay in touch socially. The need for appreciation will certainly not be achieved if the elderly do not respect others. When it examined through social exchange theory, humans tend to have interpersonal relationships because of the desire to get benefits after providing benefits. As for the context of the elderly's life, when elderly gets various respect from both family and society, of course the elderly will also try to provide feedback in the form of appreciation then. Jane and Abidin (2020) stated several reasons why elderly still want to work or be economically independent, namely: the desire to fulfill their own needs without depending on their family, reluctance to be silent and fill their free time so that they can give benefits to their family and others.

For the elderly, conformity and respect to others is something that can give meaning to their life. Conformity according to Soekanto (2003) is a process of adapting oneself to the society, by respecting the norms and values of the society. Myers (2010) defined conformity as a change in behavior or belief as a result of the real or imagined group pressure. Conformity consists of two elements, namely acceptance and compliance (Myers, 2010). Acceptance is a conformity which includes actions and beliefs to conform to social pressures while fulfillment is a reaction of agreeing even though they do not really agree. A research conducted by Lestari (2017) found that elderly have a more meaningful life when they can stay in touch with friends.

The social needs of elderly are quite diverse. The diversity of social needs in elderly needs to be expressed so that it can be seen which differences and needs of elderly are high. The results of this study are expected to provide an overview of the social needs of elderly so that it can be a contribution to the South Bangka regional government in making related policies. The hypothesis in this study is that there is a difference between need of affiliation, need of succorance, and need of deference.

\section{Method}

The social needs of elderly in South Bangka Regency were expressed through need of affiliation, need of succorance and need of deference. There were 311 elderly subjects from 8 (eight) sub-districts in South Bangka Regency which determined by using proportional sampling technique based on the area of each district. All subjects were elderly at aged 61-92 years. The male elderly involved in this study were 134 
people and the female elderly were 177 people. The data analysis using Anova with the SPSS version 23 application, but before that, it is necessary to test for normality and homogeneity.

\section{Result And Discussion}

Table 1. The Mean Rank Needs on Elderly

\begin{tabular}{|c|c|c|}
\hline No. & Needs & Mean Ranks \\
\hline 1. & Succorance & 548.09 \\
\hline 2. & Affiliation & 541.72 \\
\hline 3. & Deference & 311.20 \\
\hline
\end{tabular}

The results of the SPSS test above indicated that there were differences in the three needs with a significance value (Asymp sig) $p<.001$. Table 1 showed that the mean ranks for needs succorance is 548.09 , needs of affiliation is in the second place with the mean rank of 541.72 and in the third place is needs of difference with the mean rank of 311.20.

The needs of succorance are the need for attention from others seems to dominate. This high score on needs indicated a desire to depend and be cared by others. The needs of succorance related to social support received by someone, especially for the elderly. Billstedt et al. (2017) in his research on elderly over 75 years, stated that the needs of succorance is one of the dominant needs in the elderly. The other research conducted by social support can sustain psychological well-being. Social support in the form of close relationships with others can be a supporting factor for psychological well-being for elderly (Winnubust in Desiningrum, 2014). When the elderly getting social support, they will feel loved, cared for and appreciated so that psychological well-being will get better as well.

Furthermore, researchers want to find out more about the spread of each of these social needs. The categorization guidelines used are as follows:

Table 2. Categorization Norms

\begin{tabular}{|c|c|c|}
\hline Formula & Range & Category \\
\hline $\begin{array}{c}\mu-3 \mathrm{SD}<\mathrm{X} \leq \mu- \\
1.5 \mathrm{SD}\end{array}$ & $0<\mathrm{X} \leq 1,5$ & Very low \\
\hline$\mu-1.5 \mathrm{SD}<\mathrm{X} \leq \mu$ & $1,5<\mathrm{X} \leq 3$ & Low \\
\hline$\mu<\mathrm{X} \leq \mu+1.5 \mathrm{SD}$ & $3<\mathrm{X} \leq 4,5$ & High \\
\hline $\begin{array}{c}\mu+1.5 \mathrm{SD}<\mathrm{X} \leq \mu \\
+3 \mathrm{SD}\end{array}$ & $4,5<\mathrm{X} \leq 6$ & Very high \\
\hline
\end{tabular}

Table 3. Need of Succorance Categorization

\begin{tabular}{|l|l|l|c|}
\hline Very low & Low & High & Very high \\
\hline $3 \%$ & $42 \%$ & $54 \%$ & $1 \%$ \\
\hline
\end{tabular}


Table 3 shows that there are $54 \%$ of the elderly people of South Bangka have a high need of succurance, there are 166 of 311 subjects. However, $42 \%$ are in the low category, there are 131 subjects. This shows that their need of succurance is not dominant in certain categories, although the tendency is high. Neugarten et. al (in Jagielska, 2020) stated that the personality type associated with high needs of succorance is passive dependent that is a personality type characterized by depending on others, seeking support and low adaptation to the old age. The results of this study indicated that the high needs of succorance among elderly in South Bangka Regency have actually encouraged their behavior to have a high closeness to neighbors. The one who can help them at any time is only their neighbors, not their children or families who are on another island separated by the ocean. So that, the need for help and support from others seemed dominant. Social support received by elderly can improve the quality of life for elderly and social support to prevent the elderly from the tendency of post-power syndrome (Cahya et al., 2019; Lailan \& Indriana, 2015). Also, the need for help and attention from others or social support became the causes of the need to interact with others or the need of affiliation is quite high.

Table 4. Need of Affiliation Categorization

\begin{tabular}{|c|c|c|c|}
\hline Very low & Low & High & Very high \\
\hline $2 \%$ & $53 \%$ & $45 \%$ & $0 \%$ \\
\hline & & & \\
\hline 7 & 164 & 139 & 0 \\
\hline
\end{tabular}

Table 4 shows that there are $53 \%$ of the elderly people of South Bangka have a low need of affiliation, there are 164 of 311 subjects. However, 43\% are in the high category, there are 1391 subjects. This shows that their need of affiliation is not dominant in certain categories, although the tendency is low. The needs of affiliation or needs to be affiliated can be interpreted as the needs to be around others and make each other happy. The needs of affiliation are also related to the need to relate to others (Engler, 2009). The needs of affiliation are also the need to join and take part with friends in groups, to be kind, to work together or to do something with others and the need to have close social interactions. High scores indicated high loyalty to social situations, easy participation and activity. The need to connect with others or needs of affiliation is also one of the dominant needs for elderly (Jagielska, 2020).

Basically, the need to connect with others is the need of all individuals regardless of the culture where the individual comes from (Hofer \& Hagemeyer, 2018). Hofer and Hagemeyer (2018) explained that meeting this need for social acceptance and connection makes people happier, while the social rejection creates negative feelings. Atkinson et al. (in Drescher \& Schultheiss, 2016) explained that people with a high needs for affiliation are motivated to seek pleasure from closeness with others, want harmonious social contact or avoid social rejection or exclusion. Social contact is important to make elderly not feel lonely. Loneliness is associated with poor perceptions of health (Moreno Minguez \& Vicente Virseda, 2019).

According to Rawlin (in Kail \& Cavanaugh, 2010), friendship during elderly is something important, because the need for elderly friendship is the same as the need for friendship at a young age and the number and quality of friendships is strongly related to the elderly's life satisfaction. The effect of neighborhood on the mental health appears to be stronger among the elderly than other adults in the general population and elderly generally spend most of their time in the surrounding environment, which has the potential to make the elderly more susceptible to be affected by their immediate environment (Miao et al., 2019). The research by Miao et al. (2019) on the elderly in China found that the elderly who live in areas with low socioeconomic levels tend to be more active in interacting with neighbors which will form high cohesiveness that is associated with low levels of depression. The research by Miao et al. (2019) is quite suitable with the 
research in South Bangka because it has the same cultural context, which is both are in eastern culture and South Bangka consisting of small islands so that it allows them to interact with each other and raises the needs of affiliation. Involvement in social activities will make the elderly welfare better (Zhang et al., 2017).

Table 5. Need of Defference Categorization

\begin{tabular}{|c|c|c|c|}
\hline Very low & Low & High & $\begin{array}{c}\text { Very } \\
\text { high }\end{array}$ \\
\hline $21 \%$ & $66 \%$ & $13 \%$ & $0 \%$ \\
\hline & & & \\
\hline 64 & 205 & 41 & 0 \\
\hline
\end{tabular}

Table 4 shows that there are $66 \%$ of the elderly people of South Bangka have a low need of defference, there are 205 of 311 subjects. This shows that their need of defference is low. The needs of deference is the lowest need compared to the other two needs measured in this study. The needs of deference can be defined as the humans need to respect and conform with others. This need naturally becomes the lowest need because self-control in elderly is getting higher during the elderly period. According to Lewis, Todd and Su (in Santrock, 2013), most the elderly are still effectively able to maintain self-control. A survey conducted by HSBC in 2007 of 21 developed and developing countries reported that the majority of elderly in their $60 \mathrm{~s}$ and 70s were able to control their lives and even the majority of elderly living in the developed countries felt having more self-control than when they were in their 40s or 50s (Santrock, 2013).

One of the important events during the elderly age that also occurred was retirement even it did not happen to all elderly (Indriana, 2012). Retirement can occur for several reasons such as feeling financially secure after considering the projected income from Social Security, retirement funds and other structured retirement plans, and personal savings as well as job loss and health problems (Indriana, 2012; Kail \& Cavanaugh, 2010). The retirement period is one of periods that can be seen as an opportunity to be more active and even seen as a period of freedom (Indriana, 2012). The needs of deference which is lower than other needs is understandable at the retirement, because there is no longer a must to obey, especially to their supervisors.

One aspect of life satisfaction in elderly is having a positive self-image. One thing that forms a positive selfimage is the culture that develops in Indonesia, that elderly is being an "elder" figure, respected and obeyed their words, as well as their children who still respect their parents are one of the factors that influence happiness in the elderly life (Indriana, 2012).

\section{Conclusion}

The results of this study concluded that the need for attention and assistance or care from others is the most dominant need for elderly in South Bangka, followed by the need to relate or establish relationships with others and the last is the need for conformity. The tendency of need od succoance is high, need o affiliation is low and need of defference is low. The suggestion that can be given based on this research is to provide a day care program for the elderly. Day care allows elderly to get proper care and keep in touch with others, especially the family. The day care program is expected to meet both physiological and social needs so that it can support the welfare of elderly. The development of elderly-friendly areas is also needed in order to remain the elderly in their activities actively so that the need for social relations can be fulfilled.

\section{References}

1. Assosiation, A. P. (n.d.). APA Dictionary of Psychology. Retrieved February 10, 2020, from https://dictionary.apa.org/edwards-personal-preference-schedule

2. Billstedt, E., Waern, M., Falk, H., Duberstein, P., Östling, S., Hällström, T., \& Skoog, I. (2017). Time Trends in Murray's Psychogenic Needs over Three Decades in Swedish 75-Year-Olds. Gerontology, 63(1), 45-54. https://doi.org/10.1159/000448113

3. Cahya, E., Harnida, H., \& Indrianita, V. (2019). Hubungan dukungan sosial dengan kualitas hidup lansia di posyandu lansia wiguna karya kebonsari surabaya. NERSMID: Jurnal Keperawatan Dan 
Kebidanan, 2(1), 33-47.

4. Chen, L., Alston, M., \& Guo, W. (2019). The influence of social support on loneliness and depression among older elderly people in China: Coping styles as mediators. Journal of Community Psychology, 47(5), 1235-1245. https://doi.org/https://doi.org/10.1002/jcop.22185

5. Cherry, K. (2020). Murray's Theory of Psychogenic Needs. https://www.verywellmind.com/murrays-theory-of-psychogenic-needs-2795952

6. Desiningrum, D. R. (2014). Kesejahteraan psikologis lansia janda/duda ditinjau dari persepsi terhadap dukungan sosial dan gender. Jurnal Psikologi Undip, 13(2), 102-106. https://doi.org/10.14710/jpu.13.2.102-201

7. Drescher, A., \& Schultheiss, O. C. (2016). Meta-analytic evidence for higher implicit affiliation and intimacy motivation scores in women, compared to men. Journal of Research in Personality, 64, 110. https://doi.org/10.1016/j.jrp.2016.06.019

8. Engler, B. (2009). Personality theories : An introduction (8th ed.). Wadsworth Cengage Learning.

9. Glicken, M. D. (2009). Evidence-based counseling and psychotherapy for an aging population. Academic Press. https://doi.org/https://doi.org/10.1016/C2009-0-01906-0

10. Hakim, L., \& Hartati, N. (2014). Sumber-sumber kebahagiaan lansia ditinjau dari dalam dan luar tempat tinggal panti jompo. Jurnal RAP UNP, 5(1), 32-42.

11. Hofer, J., \& Hagemeyer, B. (2018). Social bonding: Affiliation motivation and intimacy motivation. In J. Heckhausen \& H. Heckhausen (Eds.), Motivation and Action (pp. 305-334). Springer International Publishing. https://doi.org/10.1007/978-3-319-65094-4_7

12. Hoyer, J. W., \& Roodin, P. . (2009). Adult development and aging (6th ed.). McGraw-Hill.

13. Indriana, Y. (2012). Gerontologi \& progeria. Pustaka Pelajar.

14. Jagielska, K. (2020). Attitudes of the elderly towards old age. Annales Universitatis Mariae Curie$\begin{array}{llllll}\text { Skłodowska, Sectio } & J & - & \text { Paedagogia-Psychologia, } & 33(1), & \end{array}$ https://doi.org/10.17951/j.2020.33.1.165-175

15. Jane, A., \& Abidin, Z. (2020). Produktif di usia lanjut: Studi fenomenologi pada pekerja adiyuswa yang pernah menjalani mobilitas. Jurnal Empati, 9(5), 431-437.

16. Kail, R. V., \& Cavanaugh, J. C. (2010). Human development: A life-span view (5th ed.). Wadsworth Cengage Learning.

17. Kim, S.-H., \& Park, S. (2017). A meta-analysis of the correlates of successful aging in older adults. Research on Aging, 39(5), 657-677. https://doi.org/10.1177/0164027516656040

18. Lailan, L. L., \& Indriana, Y. (2015). Dukungan sosial dan kecenderungan post power syndrome pada pensiunan tni dan polri anggota persatuan purnawirawan dan warakawuri tni dan polri dpc pepabri kabupaten banyumas. Empati, 4(4), 113-117.

19. Lestari, M. D. (2017). Persahabatan: Makna dan kontribusinya bagi kebahagiaan dan kesehatan lansia. Jurnal Psikologi Ulayat, 4(1), 59-82. https://doi.org/https://doi.org/10.24854/jpu12017-80

20. Medawati, R., Haryanto, J., \& Ulfiana, E. (2020). Analisis faktor successful aging pada lansia yang bekerja sebagai petani. Indonesian Journal of Community Health Nursing, 5(1), 26. https://doi.org/10.20473/ijchn.v5i1.18704

21. Miao, J., Wu, X., \& Sun, X. (2019). Neighborhood, social cohesion, and the elderly's depression in Shanghai. Social Science and Medicine, 229(June 2018), 134-143. https://doi.org/10.1016/j.socscimed.2018.08.022

22. Miller, R. (2012). Intimate relationships (6th ed.). McGraw-Hill.

23. Moreno Mínguez, A., \& Vicente Vírseda, J. A. (2019). Well-being and living arrangement of elderly people from European comparative perspective. The Social Science Journal, 56(2), 228-242. https://doi.org/https://doi.org/10.1016/j.soscij.2018.11.007

24. Myers, D. G. (2010). Social psychology (10th ed.). McGraw-Hill.

25. Olson, M. H., \& Hergenhahn, B. R. H. (2010). An introduction to theories of personality (8th ed.). Pearson.

26. Papalia, D. E., Olds, S. W., \& Feldman, R. D. (2007). Human development (10th ed.). McGraw-Hill.

27. Şahin, D. S., Özer, Ö., \& Yanardăg, M. Z. (2019). Perceived social support, quality of life and satisfaction with life in elderly people. Educational Gerontology, 45(1), 69-77. https://doi.org/10.1080/03601277.2019.1585065

28. Sanjaya, A., \& Rusdi, I. (2012). Hubungan interaksi sosial dengan kesepian pada lansia. Jurnal 
Keperawatn Holistik, 1(3), 26-31.

29. Santrock, J. W. (2013). Life-span development (14th ed.). McGraw-Hill.

30. Sari, D. M. P., Lestari, C. Y. D., Putra, E. C., \& Nashori, F. (2018). Kualitas hidup lansia ditinjau dari sabar dan dukungan sosial. Jurnal Ilmiah Psikologi Terapan, 6(2), 131-141. https://doi.org/https://doi.org/10.22219/jipt.v6i2.5341

31. Soekanto, S. (2003). Sosiologi: Suatu pengantar. Raja Grafindo Persada.

32. Suardiman, S. P. (2011). Psikologi usia lanjut. Gadjah Mada University Press.

33. Taylor, S. E., Peplau, L. A., \& Sears, D. O. (2006). Social psychology (12th ed.). Pearson.

34. Xie, H., Peng, W., Yang, Y., Zhang, D., Sun, Y., Wu, M., Zhang, J., Jia, J., \& Su, Y. (2018). Social support as a mediator of physical disability and depressive symptoms in Chinese elderly. Archives of Psychiatric Nursing, 32(2), 256-262. https://doi.org/https://doi.org/10.1016/j.apnu.2017.11.012

35. Zhang, W., Feng, Q., Lacanienta, J., \& Zhen, Z. (2017). Leisure participation and subjective wellbeing: Exploring gender differences among elderly in Shanghai, China. Archives of Gerontology and Geriatrics, 69, 45-54. https://doi.org/https://doi.org/10.1016/j.archger.2016.11.010 